\title{
ОПЫТ РАБОТЫ ЭНДОКРИНОЛОГИЧЕСКОЙ ГРУППЫ ДЕТЕЙ С САХАРНЫМ ДИАБЕТОМ В ДОШКОЛЬНОМ ОБРАЗОВАТЕЛЬНОМ УЧРЕЖДЕНИИ
}

\author{
Г.Н. Шипилова, Е.А. Коваленко, Е.Ю. Баталина, Я.В. Гирш \\ БУ «Сургутская городская клиническая поликлиника №5», г. Сургут, ХМАО-Югра
}

Для каждой семьи с ребенком дошкольного возраста с сахарным диабетом (СД) встает первоочередная проблема - оформление ребенка в дошкольное образовательное учреждение (ДОУ).

В июле 2015 г. на заседании Общественного совета при БУ «Сургутская городская клиническая поликлиника №5» представители организации пациентов «Надежда» детей с сахарным диабетом, врачи эндокринологи, представители администрации города Сургута обсудили необходимость создания в городе отдельной группы в ДОУ с возможностью получения дошкольного образования и специализированной медицинской помощи. Осенью 2015 года получен положительный ответ о возможности открытия специализированной разновозрастной группы на базе МБДОУ № 40 «Снегурочка», обслуживающийся БУ «Сургутская городская клиническая поликлиника №5».

ЦЕЛЬ - проанализировать результаты функционирования специальной группы для детей с сахарным диабетом в ДОУ.

В сентябре 2016 г. открыта эндокринологическая группа детей с сахарным диабетом 1 типа, задачами которой были:

- предоставление возможности детям с СД посещать дошкольное образовательное учреждение;

- расширение возможностей родителей детей с СД заниматься своей профессиональной деятельностью;

- контроль уровня глюкозы крови во время пребывания ребенка в дОУ с коррекцией инсулинотерапии;

- адаптация детей к социуму;

- подготовка к школе.

Ежегодно количество детей с сахарным диабетом дошкольного возраста увеличивается. Осенью 2019 года было принято решение открыть вторую группу в том же дошкольном образовательном учреждение с разделением детей по возрасту. На данный момент группы посещают 24 ребенка от 2 лет до 7 лет, набор детей продолжается.

Группу наблюдает врач-детский эндокринолог. Медицинские сестры прошли обучение и получили навыки практической работы на базе БУ ХМАО-Югры «Сургутской городской клинической больницы», где оказывается специализированная помощь детям с СД, а в марте 2016 года на выездном семинаре в г. Москва получено удостоверение о повышение квалификации «Участие медицинских сестер в оказании помощи больным с сахарным диабетом».

Контроль уровня сахара крови осуществляется медицинскими сестрами на протяжении всего дня каждые 30 мин, по мере необходимости, чаще. У 55\% детей установлены системы непрерывного мониторинга глюкозы, что позволяет наблюдать за уровнем глюкозы крови в режиме реального времени, 85\% детей группы получают терапию с помощью инсулиновых помп. После измерения уровня глюкозы в крови, с учетом съеденных углеводов и углеводных коэффициентов детям вводится инсулин с помощью шприц-ручек и инсулиновых помп.

Вся полученная информация записывается медицинскими сестрами в дневники самоконтроля каждого ребенка, в которых указываются:

- уровень глюкозы в крови в течение дня;

- количество съеденных углеводов;

- количество введенного инсулина;

- замена инфузионного набора, батареек, других расходных материалов.

Ведение дневника позволяет объективно оценивать полученные результаты, а при необходимости вносить соответствующие изменения в питание и схемы лечения, что является надежным средством предупреждения развития гипо- и гипергликемических состояний. 


\section{СБОРНИК ТЕЗИСОВ}

XVII Российская научно-практическая конференция детских эндокринологов «Достижения науки в практику детского эндокринолога»

Диета при сахарном диабете является необходимой составной частью лечения. Задачей диетотерапии при сахарном диабете является обеспечение равномерного и адекватного физической нагрузке поступления углеводов в организм больного. Следует полностью исключить легкоусвояемые углеводы из рациона питания, за исключением случаев гипогликемии. В специализированной группе перед каждым приемом пищи взвешивается каждый продукт питания для подсчета количества углеводов в фиксированные часы. Кроме основных приемов пищи, в питание детей включены легкие перекусы.

Медицинскими сестрами проводится дополнительное обучение детей навыкам самоконтроля при сахарном диабете. Обученным и социализированным детям легче адаптироваться в будущем к школьным условиям, что позволяет избежать осложнений в состоянии психического и физического здоровья.

Выводы: Социализация является наиболее важным фактором дальнейшего развития ребенка с СД. Понимание проблем, связанных с сахарным диабетом, со стороны медицинского персонала и педагогов, их поддержка, взаимодействие, умение грамотно реагировать на возможные изменения самочувствия - залог спокойствия самого ребенка и родителей. 